\title{
Faktor Risiko Kurang Energi Kronis (KEK) pada Ibu Hamil di Cikembar Kabupaten Sukabumi
}

\author{
Muh. Guntur Sunarjono Putra ${ }^{*}$, Mira Dewi ${ }^{2}$ \\ ${ }^{1)}$ Departemen Gizi Masyarakat, Fakultas Ekologi Manusia, Institut Pertanian Bogor, \\ muh_guntursunarjonoputra@apps.ipb.ac.id \\ ${ }^{2}$ Departemen Gizi Masyarakat, Fakultas Ekologi Manusia, Institut Pertanian Bogor, \\ mirade@apps.ipb.ac.id
}

\begin{abstract}
ABSTRAK
Salah satu masalah gizi utama di Indonesia adalah Kurang Energi Kronis (KEK) pada ibu hamil yang merupakan penyebab tingginya angka kematian ibu dan berat bayi lahir rendah. Penelitian ini bertujuan menganalisis faktorfaktor risiko KEK pada ibu hamil dengan desain studi potong lintang. Subjek penelitian ini adalah ibu hamil KEK dan normal sebanyak 70 orang di Puskesmas Cikembar, Kabupaten Sukabumi. Kelompok KEK memiliki tingkat pengetahuan gizi dan kesehatan yang relatif kurang dibandingkan kelompok normal. Tingkat kecukupan energi dan protein pada kedua kelompok umumnya berada pada kategori defisit. Sebagian besar ketahanan pangan kelompok KEK berada pada kondisi rawan pangan dan kelompok normal berada pada kondisi rentan pangan. Berdasarkan hasil analisis regresi logistik menunjukkan bahwa terdapat hubungan yang signifikan antara pengetahuan ibu dan ketahanan pangan rumah tangga dengan kejadian KEK pada ibu hamil ( $p<0.05)$, namun antara tingkat kecukupan energi dan protein menunjukkan hubungan yang tidak signifikan ( $p>0.05)$. Hasil dari analisis regresi logistik berganda menunjukkan bahwa faktor yang mempengaruhi kejadian KEK pada ibu hamil adalah ketahanan pangan rumah tangga. Selain itu, tingkat pengetahuan gizi dan kesehatan, konsumsi pangan, dan ketahanan pangan rumah tangga pada ibu hamil KEK berada dalam kondisi yang rendah atau defisit dibandingkan ibu hamil normal.
\end{abstract}

Kata kunci: ibu hamil, konsumsi pangan, kurang energi kronis, pengetahuan gizi

\begin{abstract}
One of the nutritional problems in Indonesia is Chronic Energy Deficiency (CED) among pregnant women, which is the cause of the high maternal mortality rate and low birth weight. This study aims to analyze the risk factors of CED in pregnant women with cross-sectional study design. The subject in this research were 70 pregnant women with and without CED (normal) at Cikembar Health Center Sukabumi district. CED group had less nutrition and health knowledge in comparison to the normal group. The level of energy and protein sufficiency in both groups was generally in the deficit category. Most of the CED group food security was in food insecurity while the normal group was in food vulnerable conditions. Based on the results of logistic regression analysis, it shows that there is a significant relationship between maternal knowledge and household food security with the incidence of CED in pregnant women ( $p<0.05)$, but between the level of energy and protein adequacy shows an insignificant relationship ( $p>0.05)$. The multiple logistic regression analysis results indicate that the factor affecting the incidence of CED in pregnant women is household food security. Besides, the level of knowledge of nutrition and health, food consumption, and household food security in CED pregnant women is low or deficit compared to the normal pregnant women.
\end{abstract}

Keywords: chronic energy deficiency, food consumption, nutritional knowledge, pregnant women

*Korespondensi Author: Muh Guntur Sunarjono Putra, Departemen Gizi Masyarakat, Fakultas Ekologi Manusia, Institut Pertanian Bogor, muh_guntursunarjonoputra@apps.ipb.ac.id, 085242633057

\section{PENDAHULUAN}

Salah satu daerah dengan Angka kematian Ibu (AKI) yang cukup tinggi adalah Kabupaten Sukabumi sebesar 109.31 per 100 000 kelahiran hidup pada tahun 2016. Angka ini lebih besar dari angka kematian ibu di Jawa Barat sebesar 84.78 per 100000 kelahiran hidup. Kurang Energi Kronis (KEK) merupakan salah satu penyebab angka kematian ibu dan bayi serta berat badan lahir rendah yang tergolong tinggi di Indonesia. Indonesia berada pada urutan keempat dengan prevalensi KEK terbesar pada ibu hamil sebesar 35.5\%. Sustainable Development Goals (SDGs) memiliki target prevalensi ibu hamil KEK turun hingga 5\% pada tahun 2015-2030. ${ }^{1,2}$ 
Data dari hasil Riset Kesehatan Dasar (Riskesdas) 2018 menunjukkan bahwa prevalensi KEK di Indonesia pada tahun 2018 adalah sebesar $17.3 \%$, sedangkan provinsi Jawa Barat sebesar $14.1 \%$. Persentase ibu hamil yang mengalami KEK di Puskesmas Cikembar Kabupaten Sukabumi sebesar $7.99 \%$. Hal ini menunjukkan bahwa data tersebut masih berada di atas target nasional pada tujuan SDGs 20152030. Walaupun angka tersebut lebih rendah dari rata-rata nasional dan di Jawa Barat, AKI di Kabupaten Sukabumi umumnya lebih tinggi dari angka nasional sehingga semua faktor yang berkontribusi terhadap masalah ini perlu mendapat perhatian. Puskesmas Cikembar termasuk 10 puskesmas dengan jumlah ibu hamil KEK tertinggi di Kabupaten Sukabumi, Kabupaten Sukabumi termasuk 100 kabupaten \& kota prioritas untuk intervensi anak yang mengalami stunting. ${ }^{3}$

Masalah-masalah yang dialami oleh ibu hamil masih perlu menjadi perhatian meskipun berbagai program perbaikan gizi telah dilakukan. Bentuk program perbaikan gizi pada ibu hamil KEK dengan Pemberian Makanan Tambahan Pemulihan (PMT-P) berupa biskuit program, biskuit selain program, susu bubuk, susu cair, bahan makanan mentah, dan bahan makanan matang. Pelaksanaan distribusi PMT-P tidak dilakukan pengawasan secara khusus terkait aturan jumlah yang harus dikonsumsi oleh ibu, sehingga seringkali makanan tersebut tidak dikonsumsi oleh ibu dan makanan diberikan kepada anggota keluarga lainnya. ${ }^{4}$

Rendahnya konsumsi energi dalam jangka panjang merupakan penyebab terjadinya KEK dan akan berisiko mengalami pendarahan, anemia, berat badan yang tetap, dan mudah terserang penyakit infeksi. Selain itu akan berdampak pada lamanya proses persalinan dan kondisi BBLR pada bayi. Faktor lain yang mendukung terjadinya KEK adalah ketahanan pangan rumah tangga yang menjadi indikator ketahanan pangan nasional. ${ }^{4,5,6}$

Berdasarkan hal tersebut, penelitian ini mengidentifikasi faktor risiko yang memengaruhi terjadinya KEK pada ibu hamil di Puskesmas Cikembar.

\section{METODOLOGI}

Penelitian ini menggunakan desain potong lintang yang dilakukan di Puskesmas Cikembar Kabupaten Sukabumi pada bulan Februari hingga Maret 2019. Kriteria inklusi pada penelitan ini adalah usia kehamilan trimester II dan III dan ibu memeriksakan diri ke KIA Puskesmas Cikembar dalam rentang waktu penelitian, Adapun kriteria eksklusi adalah ibu menderita penyakit kronis dan kelainan kongenital pada janin.

Jumlah subjek pada penelitian ini terdiri dari 35 ibu hamil KEK (LILA $<23.5 \mathrm{~cm}$ ) yang memenuhi kriteria, 35 subjek ibu hamil dengan status gizi normal dipilih secara acak (random sampling) dan dimasukkan kedalam kelompok normal. Penelitian ini telah disetujui oleh Komisi Etik Penelitian yang Melibatkan Subjek Manusia Institut Pertanian Bogor dengan Nomor 154/IT3.KEPMSM-IPB/SK/2019.

Data yang dikumpulan terdiri dari data primer dan data sekunder. Data primer terdiri dari pengetahuan gizi, kesehatan dan kehamilan, riwayat kesehatan kehamilan, dan konsumsi pangan dikumpulkan melalui wawancara dan self report dengan alat bantu kuesioner yang diisi oleh subjek setelah mendapat penjelasan dari peneliti dan bersedia menjadi subjek penelitian sedangkan antropometri ibu hamil (LILA) menggunakan pita LILA. Pengukuran berat badan dan tinggi badan sebelum hamil dengan menanyakan kepada subjek.

Data konsumsi pangan dilakukan selama 2x24 jam (weekday dan weekend) serta FFQ agar dapat menggambarkan pola konsumsi pangan subjek 1 bulan yang lalu. Konversi data asupan makanan dan minuman menggunakan Tabel Komposisi Pangan Indonesia (TKPI) dan Nutrition Fact pada pangan kemasan sebagai rujukan kandungan energi dan protein yang terkandung di dalam suatu makanan ataupun minuman yang digunakan di Indonesia. Data sekunder dikumpulkan terdiri dari gambaran umum Puskesmas Cikembar.

Data akan melalui proses editing dan pengkodean sebelum diolah dan dianalisis menggunakan Microsoft Excel 2010 dan SPSS 16.0 for windows. Analisis bivariat menggunakan uji regresi logistik untuk melihat 
hubungan dan peluang antara tingkat kecukupan energi, tingkat kecukupan protein, pengetahuan gizi, kesehatan, dan kehamilan, serta ketahanan pangan rumah tangga terhadap kejadian KEK pada ibu hamil, sedangkan analisis multivariat menggunakan uji regresi logistik berganda untuk melihat faktor yang paling berpengaruh terhadap kejadian KEK dengan variabel usia, tingkat pendapatan keluarga, besar keluarga, pengetahuan gizi, kesehatan, dan kehamilan, tingkat kecukupan protein, dan ketahanan pangan rumah tangga. Uji beda dilakukan menggunakan uji Mann-Whitney dikarenakan data tidak terdistribusi normal

\section{HASIL DAN PEMBAHASAN}

\section{Jarak Kehamilan dan Paritas}

Kejadian KEK salah satunya dipengaruhi oleh faktor biologis yang meliputi jarak kehamilan dan paritas. Jarak kehamilan yang singkat akan berpengaruh pada cadangan atau ketersediaan zat gizi tubuh ibu dan daya penyerapan zat gizi tergolong rendah. Semakin banyak jumlah kehamilan dan kelahiran $(\geq 4)$ maka berpotensi memiliki status gizi yang kurang. ${ }^{7}$ Penelitian ini menunjukkan bahwa hampir semua subjek ibu hamil memiliki jarak kehamilan $\geq 2$ tahun (94.3\%) yang sudah berada dalam kategori tidak berisiko.

Tabel 1. Sebaran subjek berdasarkan jarak antar kehamilan dan paritas

\begin{tabular}{|c|c|c|c|c|c|}
\hline \multirow{2}{*}{ Kategori } & \multicolumn{2}{|c|}{ KEK } & \multicolumn{2}{|c|}{ Normal } & \multirow{2}{*}{$p$-value } \\
\hline & $\mathrm{n}$ & $\%$ & $\mathbf{n}$ & $\%$ & \\
\hline \multicolumn{6}{|l|}{ Jarak } \\
\hline \multicolumn{6}{|l|}{ kehamilan $^{8}$} \\
\hline $\begin{array}{l}\text { - Berisiko } \\
\quad(<2 \text { tahun })\end{array}$ & 2 & 5.7 & 2 & 5.7 & $1.000^{\mathrm{a}}$ \\
\hline \multicolumn{6}{|l|}{ - Tidak } \\
\hline $\begin{array}{l}\text { Berisiko } \\
\text { ( } \geq 2 \text { tahun) }\end{array}$ & 33 & 94.3 & 33 & 94.3 & \\
\hline \multicolumn{6}{|l|}{ Paritas 9} \\
\hline $\begin{array}{l}\text { - Berisiko } \\
(\geq 4)\end{array}$ & 1 & 2.9 & 2 & 5.7 & $0.558^{a}$ \\
\hline $\begin{array}{l}- \text { Tidak } \\
\text { berisiko } \\
(1-3)\end{array}$ & 34 & 97.1 & 33 & 94.3 & \\
\hline
\end{tabular}

Jarak kehamilan yang berdekatan akan meningkatkan risiko mengalami gangguan kesehatan selama masa kehamilan dan akan berdampak pada pertumbuhan dan perkembangan janin. Selain itu, apabila dilihat dari masing-masing kelompok menunjukkan sebagian besar termasuk dalam kategori tidak berisiko. Hal ini dapat terjadi dikarenakan kedua kelompok subjek sebagian besar masih berada pada kondisi kehamilan anak pertama. Pengkategorian paritas didasarkan jumlah anak yang pernah dilahirkan (hidup dan meninggal) dan jika anak lebih dari sama dengan 4 maka termasuk risiko tinggi, serta anak 1-3 maka termasuk kategori risiko rendah. Paritas yang tinggi dapat membahayakan ibu hamil dikarenakan proses pemulihan rahim belum optimal untuk menyokong janin berikutnya sehingga jarak kehamilan yang dianjurkan adalah minimal 2 tahun. ${ }^{10,11,12}$ Hasil penelitian menunjukkan bahwa tidak terdapat perbedaan yang bermakna pada ibu hamil KEK dan normal berdasarkan kategori jarak kehamilan dan paritas $(\mathrm{p}>0.05)$.

\section{Indeks Massa Tubuh (IMT) Pra-hamil}

Status gizi adalah suatu keadaan atau kondisi tubuh pada seseorang yang dapat dilihat dari konsumsi pangan dan penggunaan zat-zat gizi di dalam tubuh. Status gizi dipengaruhi oleh asupan zat gizi. Kekurangan berbagai macam zat gizi selama kehamilan akan mempengaruhi status gizi ibu hamil.Status gizi dapat diketahui dengan pengukuran dan penilaian dengan menggunakan beberapa indikator seperti LILA, penambahan berat badan selama kondisi hamil, dan IMT sebelum hamil. IMT pra-hamil memiliki indikator pada berat badan dan tinggi badan yang menjadi perhatian, hal ini dikarenakan memiliki pengaruh yang besar terhadap berat badan lahir bayi saat kelahiran. IMT ibu selama masa kondisi hamil yang tergolong obesitas memiliki hubungan yang erat dengan risiko gangguan pada fisiologi tubuh ibu seperti preeklampsia atau eklampsia, persalinan dengan induksi, bayi dengan makrosomia, pendarahan postpartum, dan mengalami kondisi seksio sesarea. Berikut adalah sebaran subjek IMT ibu pra-hamil (Tabel 2). 13,14 
Tabel 2. Sebaran subek berdasarkan IMT ibu

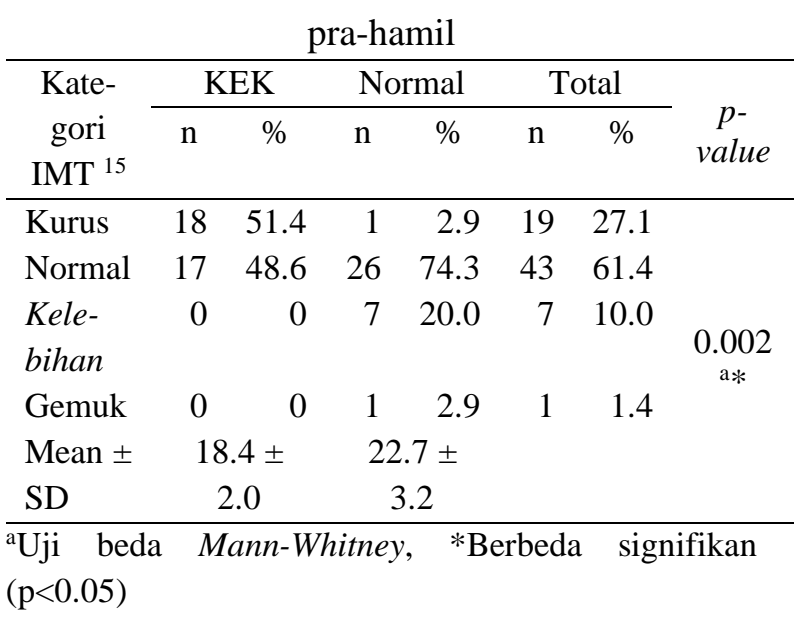

Penelitian ini menunjukkan bahwa sebagian besar subjek mempunyai IMT prahamil dalam kategori normal (61.4\%) pada ibu hamil KEK dan normal. Berdasarkan uji regresi logistik menunjukkan bahwa terdapat hubungan yang signifikan antara IMT pra-hamil dengan KEK pada ibu hamil ( $p$-value $=0.023)$ dan OR insidens terjadinya KEK pada ibu hamil dengan IMT pra-hamil adalah 27.5 (95\% CI: 3.356225.806) yang bermakna bahwa ibu hamil dengan kondisi IMT pra-hamil kategori kurus akan berisiko sebesar 27.5 kali lebih tinggi untuk mengalami KEK dibandingkan ibu hamil dengan IMT pra-hamil kategori normal. Penelitian ini sejalan yang dilakukan di Yogyakarta menunjukkan bahwa terdapat hubungan yang signifikan antara IMT pra-hamil dengan LILA pada ibu hamil ( $p$-value $=0.001$ ). Kekuatan hubungan yang relatif lebih rendah dalam penelitian ini disebabkan oleh usia kehamilan ibu yang relatif lebih tua dibanding penelitian di Jogjakarta, sehingga lebih dipengaruhi asupan gizi selama hamil. ${ }^{16}$ Selain itu, penelitian ini menunjukkan bahwa terdapat perbedaan yang bermakna pada ibu hamil KEK dan normal berdasarkan kategori IMT $(p<0.05)$.

Secara umum, wanita yang memiliki LILA yang besar maka akan memiliki IMT yang besar. Hal ini dikarenakan LILA terdiri dari otot, lemak, dan tulang. IMT pra-hamil ataupun dalam masa kehamilan akan bertambah bila ukuran LILA bertambah $1 \mathrm{~cm}$ dan umur bertambah 1 tahun. Setiap kenaikan $1 \mathrm{~cm}$ ukuran
LILA maka akan meningkatkan IMT sebesar $0.815 \mathrm{~kg} / \mathrm{m}^{2} .{ }^{17}$

\section{Pengetahuan gizi, kesehatan, dan kehamilan}

Pengetahuan diartikan sebagai sesuatu yang telah diketahui oleh seseorang atau hasil pekerjaan untuk menjadi tahu. Subjek diberikan 20 pertanyaan untuk mengetahui tingkat pengetahuan ibu hamil. Tingkat pengetahuan gizi dibagi menjadi 3 kategori yaitu kurang (<60\%), cukup (60-79\%), dan baik ( $\geq 80 \%)$. ${ }^{18,19}$

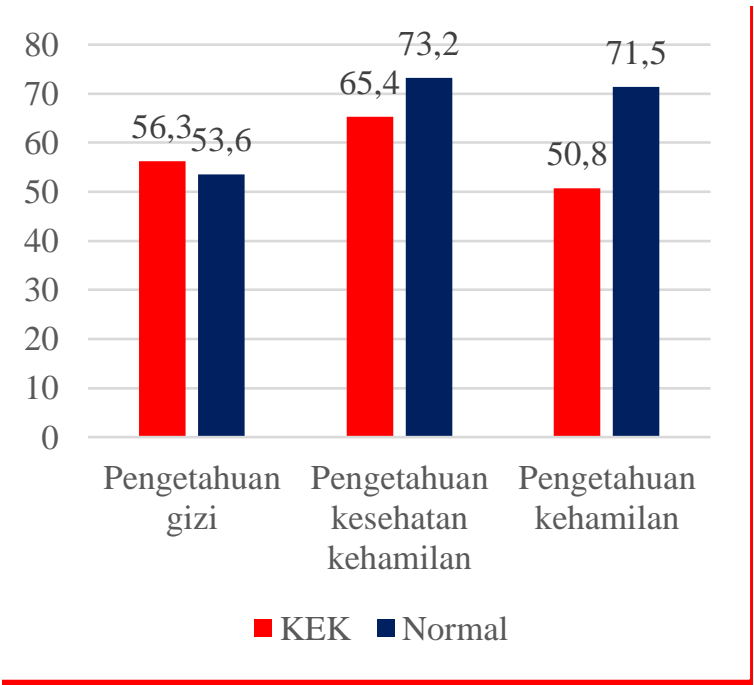

Gambar 1. Sebaran subjek berdasarkan item pertanyaan pengetahuan gizi, kesehatan, dan kehamilan

Berdasarkan gambar 1, menunjukkan bahwa item pertanyaan pengetahuan gizi pada ibu hamil KEK memiliki rata-rata persentase yang menjawab benar lebih tinggi dibandingkan ibu normal, sedangkan pada item pertanyaan pengetahuan kesehatan kehamilan, dan pengetahuan terhadap kehamilan ibu hamil normal memiliki persentase yang menjawa benar lebih tinggi dibandingkan ibu hamil KEK. Adapun item pertanyaan pengetahuan gizi yang memiliki tingkat kesalahan tertinggi pada 2 kelompok subjek terkait manfaat atau kegunaan dari zat gizi khususnya protein yang ditandai dengan persentase pada kelompok KEK (20.0\%) dan normal (14.3\%). Item pengetahuan kesehatan kehamilan yang memiiki tingkat kesalahan tertinggi pada 2 kelompok terkait 
sikap ibu terhadap peningkatan berat badan selama kehamilan ditandai dengan persentase pada kelompok KEK (2.9\%) dan normal (5.7\%). Item pertanyaan terakhir mengenai pengetahuan kehamilan yang memiliki tingkat kesalahan tertinggi pada 2 kelompok terkait total pertambahan berat badan ibu hamil selama kehamilan pada kelompok KEK (22.9\%) dan normal (48.6\%). Hasil dari penelitian ini dapat menjadi masukan bagi puskesmas dalam pemberian penyuluhan atau pendidikan gizi kepada ibu hamil agar terjadinya peningkatan pengetahuan ibu. Berikut adalah sebaran subjek berdasarkan tingkat pengetahuan gizi, kesehatan dan kehamilan (Tabel 3).

Tabel 3. Sebaran subjek berdasarkan tingkat pengetahuan gizi, kesehatan dan kehamilan

\begin{tabular}{|c|c|c|c|c|c|c|c|}
\hline \multirow{2}{*}{$\begin{array}{l}\text { Kate- } \\
\text { gori }^{19}\end{array}$} & \multicolumn{2}{|c|}{ KEK } & \multicolumn{2}{|c|}{ Normal } & \multicolumn{2}{|c|}{ Total } & \multirow{2}{*}{$\begin{array}{c}p- \\
\text { value }\end{array}$} \\
\hline & $\mathrm{n}$ & $\%$ & $\mathrm{n}$ & $\%$ & $\mathrm{n}$ & $\%$ & \\
\hline $\begin{array}{l}\text { Kurang } \\
(<60 \%)\end{array}$ & 18 & 51.4 & 8 & 22.9 & 26 & 37.1 & \\
\hline $\begin{array}{l}\text { Cukup } \\
(60- \\
79 \%)\end{array}$ & 13 & 37.1 & 19 & 54.3 & 32 & 45.7 & $\underset{\mathrm{a}^{*}}{0.016}$ \\
\hline $\begin{array}{l}\text { Baik } \\
\geq 80 \% \text { ) }\end{array}$ & 4 & 11.4 & 8 & 22.9 & 12 & 17.1 & \\
\hline
\end{tabular}

Tingkat pengetahuan gizi, kesehatan, kehamilan pada ibu hamil KEK dan normal yang berada dalam kategori cukup (45.7\%), kurang (37.1\%), dan baik (17.1\%). Selain itu, apabila dibandingkan berdasarkan tingkat pengetahuan gizi, kesehatan, dan kehamilan pada 2 kelompok, sebagian besar persentase pada kelompok ibu hamil normal berada dalam kategori cukup (54.3\%) dan baik (22.9\%) dibandingkan ibu hamil KEK berada dalam kategori yang kurang (51.4\%). Tingkat pengetahuan ibu hamil yang berada dalam kategori kurang akan berdampak pada konsumsi energi dan protein sehingga berpengaruh terhadap status gizi. ${ }^{20}$ Hasil dari penelitian ini menunjukkan bahwa terdapat perbedaan yang bermakna pada ibu hamil KEK dan normal berdasarkan kategori tingkat pengetahuan gizi, kesehatan, dan kehamilan $(\mathrm{p}<0.05)$.

Konsumsi Pangan
Keberagaman konsumsi pangan dapat digunakan sebagai indikator dalam menentukan kualitas konsumsi pangan, sehingga semakin beragam konsumsi pangan maka akan semakin pemenuhan kebutuhan zat gizi dapat terpenuhi.

Tabel 4. Sebaran subjek berdasarkan frekuensi konsumsi pangan

\begin{tabular}{|c|c|c|c|}
\hline \multirow[t]{2}{*}{ Kategori } & \multirow{2}{*}{$\begin{array}{c}\text { Jenis } \\
\text { Pangan }\end{array}$} & \multicolumn{2}{|c|}{$\begin{array}{c}\text { Rerata frekuensi } \\
(\mathrm{kali} / \mathrm{minggu}) \pm \mathrm{SD}\end{array}$} \\
\hline & & KEK & Normal \\
\hline \multirow{5}{*}{$\begin{array}{l}\text { Makanan } \\
\text { Pokok }\end{array}$} & Nasi & $16.1 \pm 4.4$ & $15.2 \pm 4.3$ \\
\hline & Terigu & $4.8 \pm 3.5$ & $3.7 \pm 3.0$ \\
\hline & Mie & $3.3 \pm 3.8$ & $3.3 \pm 5.1$ \\
\hline & Roti & $3.0 \pm 3.1$ & $2.7 \pm 2.4$ \\
\hline & $\begin{array}{l}\text { Singkong/ } \\
\text { ubi }\end{array}$ & $1.4 \pm 2.8$ & $1.2 \pm 1.8$ \\
\hline \multirow{5}{*}{$\begin{array}{l}\text { Ikan dan } \\
\text { hasil } \\
\text { olahan }\end{array}$} & Ikan asin & $4.7 \pm 4.8$ & $5.0 \pm 3.8$ \\
\hline & Ikan segar & $3.4 \pm 4.2$ & $2.4 \pm 1.5$ \\
\hline & Udang & $1.3 \pm 4.3$ & $0.5 \pm 1.1$ \\
\hline & Cumi & $1.0 \pm 3.6$ & $0.8 \pm 1.3$ \\
\hline & Hati ayam & $0.1 \pm 0.5$ & $0.1 \pm 0.5$ \\
\hline \multirow{7}{*}{$\begin{array}{l}\text { Daging, } \\
\text { telur, dan } \\
\text { hasil } \\
\text { olahan }\end{array}$} & Telur ayam & $7.0 \pm 7.1$ & $5.3 \pm 2.6$ \\
\hline & Daging & & \\
\hline & $\begin{array}{l}\text { ayam } \\
\text { Daging }\end{array}$ & $3.3 \pm 5.5$ & $2.7 \pm 1.7$ \\
\hline & sapi & $0.8 \pm 2.5$ & $0.6 \pm 1.2$ \\
\hline & Sosis & & \\
\hline & Nugget & $0.7 \pm 1.4$ & $1.1 \pm 1.2$ \\
\hline & & $0.6 \pm 1.6$ & $0.8 \pm 1.0$ \\
\hline \multirow{6}{*}{$\begin{array}{l}\text { Kacang- } \\
\text { kacangan } \\
\text { dan } \\
\text { Jhasil } \\
\text { olahan }\end{array}$} & Tahu & $6.9 \pm 6.2$ & $5.0 \pm 2.4$ \\
\hline & Tempe & $6.1 \pm 5.0$ & $5.4 \pm 4.0$ \\
\hline & $\begin{array}{l}\text { Kacang } \\
\text { tanah }\end{array}$ & $3.1 \pm 5.8$ & $1.6 \pm 2.9$ \\
\hline & $\begin{array}{l}\text { Kacang } \\
\text { hijau }\end{array}$ & $2.1 \pm 4.2$ & $1.4 \pm 1.3$ \\
\hline & Susu & $1.2 \pm 3.6$ & $1.1 \pm 2.8$ \\
\hline & kedelai & & \\
\hline \multirow{5}{*}{$\begin{array}{l}\text { Sayur- } \\
\text { sayuran }\end{array}$} & Bayam & $4.3 \pm 4.8$ & $4.1 \pm 6.4$ \\
\hline & Kang-kung & $2.9 \pm 5.1$ & $3.2 \pm 5.7$ \\
\hline & Menti-mun & $2.7 \pm 4.8$ & $3.4 \pm 5.2$ \\
\hline & $\begin{array}{l}\text { Daun } \\
\text { singkong }\end{array}$ & $2.5 \pm 5.4$ & $2.1 \pm 5.2$ \\
\hline & Buncis & $2.2 \pm 3.4$ & $2.3 \pm 3.3$ \\
\hline \multirow{5}{*}{$\begin{array}{l}\text { Buah- } \\
\text { buahan }\end{array}$} & Jeruk & $2.7 \pm 3.6$ & $3.3 \pm 4.7$ \\
\hline & Pisang & $2.0 \pm 1.8$ & $2.7 \pm 4.7$ \\
\hline & Apel & $1.3 \pm 1.6$ & $0.8 \pm 1.0$ \\
\hline & Jambu & $1.2 \pm 1.4$ & $1.8 \pm 1.6$ \\
\hline & Rambu-tan & $1.0 \pm 1.6$ & $1.2 \pm 2.6$ \\
\hline \multirow{6}{*}{$\begin{array}{l}\text { Susu dan } \\
\text { hasil } \\
\text { olahan }\end{array}$} & $\begin{array}{l}\text { Susu ibu } \\
\text { hamil }\end{array}$ & $3.7 \pm 3.7$ & $3.6 \pm 5.2$ \\
\hline & Es krim & $1.1 \pm 2.7$ & $0.9 \pm 2.9$ \\
\hline & $\begin{array}{l}\text { Susu } \\
\text { kental }\end{array}$ & $07+17$ & $06+10$ \\
\hline & manis & & \\
\hline & Yoghurt & $0.6 \pm 2.4$ & $0.6 \pm 2.5$ \\
\hline & Keju & $0.5 \pm 1.4$ & $0.5 \pm 1.1$ \\
\hline
\end{tabular}




\begin{tabular}{llcc}
\hline \multirow{2}{*}{ Kategori } & \multirow{2}{*}{$\begin{array}{c}\text { Jenis } \\
\text { Pangan }\end{array}$} & \multicolumn{2}{c}{$\begin{array}{c}\text { Rerata frekuensi } \\
\text { (kali/minggu } \pm \text { SD }\end{array}$} \\
\cline { 3 - 4 } & KEK & Normal \\
\hline \multirow{3}{*}{ Makanan } & Gorengan & $3.5 \pm 3.3$ & $3.3 \pm 2.9$ \\
jajanan & Biskuit & $3.0 \pm 2.2$ & $2.2 \pm 2.2$ \\
& Wafer & $2.7 \pm 4.0$ & $2.0 \pm 2.3$ \\
& Cilok & $1.6 \pm 2.1$ & $1.2 \pm 1.4$ \\
& baslok & $1.4 \pm 1.6$ & $1.3 \pm 1.6$ \\
\hline
\end{tabular}

Makanan pokok yang sering dikonsumsi oleh kedua kelompok adalah nasi. Kondisi ini apabila dilihat dari frekuensi konsumsi nasi per hari sebesar 2 kali. Jenis pangan pokok kedua yang sering dikonsumsi adalah tepung terigu. Hal ini berkaitan dengan ibu hamil KEK dan normal sering mengonsumsi gorengan berupa bala-bala atau bakwan. Jenis pangan yang jarang dikonsumsi adalah singkong atau ubi. Ikan dan hasil olahan yang paling sering dikonsumsi oleh kedua kelompok adalah ikan asin. Frekuensi yang sering dikonsumsi kedua oleh kedua kelompok adalah ikan segar. Rata-rata konsumsi ikan pada kedua kelompok adalah 1 kali per hari dengan jenis ikan asin maupun ikan segar. Jenis pangan yang jarang dikonsumsi adalah hati ayam.

Daging, telur, dan hasil olahannya yang paling sering dikonsumsi pada kedua kelompok adalah telur ayam dengan rata-rata frekuensi sebesar 1 kali per hari. Telur sebagai sumber protein yang memiliki kandungan asam amino paling lengkap dibandingkan makanan lainnya seperti ikan dan daging ayam, serta jenis pangan kedua yang sering dikonsumsi adalah daging ayam. Jenis pangan yang jarang dikonsumsi adalah nugget. Kacang-kacangan merupakan bahan pangan yang memiliki kandungan protein yang berasal dari tumbuhan. Peningkatan pemanfaatan berbagai macam olahan kacangkacangan perlu untuk dilakukan karena sebagai sumber protein yang potensial.Jenis pangan kacang-kacangan dan hasil olahan yang paling sering dikonsumsi adalah tahu dengan rata-rata frekuensi 1 kali per hari pada ibu hamil KEK dan 0.71 kali per hari. Jenis pangan kedua yang sering dikonsumsi adalah tempe. Konsumsi tahu dan tempe tergolong tinggi, hal ini dikarenakan harga bahan pangan terjangkau bagi subjek.
Sayur-sayuran yang sering dikonsumsi adalah bayam, dengan rata-rata frekuensi pada ibu hamil KEK 0.61 kali per hari dan 0.58 kali per hari pada ibu hamil normal. Jenis pangan kedua yang sering dikonsumsi adalah kangkung dan jenis pangan yang jarang dikonsumsi adalah buncis. Buah-buahan merupakan tanaman hortikultura yang memiliki peranan dalam sumber karbohidrat, vitamin, mineral, serat, dan antioksidan dalam tubuh. Jenis pangan buahbuahan yang sering dikonsumsi oleh kedua kelompok adalah jeruk Jenis pangan kedua yang sering dikonsumsi adalah pisang dan jenis pangan yang jarang dikonsumsi adalah rambutan.

Susu dan hasil olahan yang paling sering dikonsumsi adalah susu ibu hamil dengan frekuensi 0.52 kali per hari pada ibu hamil KEK dan 0.51 kali per hari pada ibu hamil normal. Jenis pangan kedua yang sering dikonsumsi adalah es krim dan jenis pangan yang jarang dikonsumsi adalah keju. Makanan jajanan di Indonesia beraneka ragam seperti gorengan, biskuit, moci, martabak telur, martabak manis, dan lain-lain. Makanan jajanan yang paling sering dikonsumsi adalah gorengan dengan frekuensi 0.5 kali per hari pada ibu hamil KEK dan 0.47 kali per hari pada ibu hamil normal. Jenis pangan kedua yang sering dikonsumsi adalah biskuit dan jenis pangan yang jarang dikonsumsi adalah keripik.

Tingkat konsumsi energi dan protein pada ibu hamil yang dibandingkan dengan kebutuhan individu dapat diketahui bahwa pada ibu hamil yang mengalami kondisi KEK memiliki tingkat kecukupan yang rendah ditandai dengan persentase sebesar $63 \%$ dan $68 \%$ sedangkan kelompok ibu hamil normal juga mengalami kecukupan zat gizi yang kurang ditandai dengan persentase sebesar $62 \%$ dan 63\%. Hal ini dikarenakan secara umum kelompok KEK dan normal mengonsumsi makanan dalam jumlah kecil atau sedikit dan frekuensi makan yang tidak sering.

Tingkat kecukupan energi subjek sebagian besar masih tergolong defisiensi energi. Sebagian besar subjek memiliki tingkat kecukupan energi tergolong defisiensi tingkat berat $(65.7 \%)$, defisiensi tingkat sedang $(14.3 \%)$, 
defisiensi tingkat ringan (12.9\%) pada kedua kelompok. Tingkat konsumsi energi dan protein pada ibu hamil yang dibandingkan dengan kebutuhan individu dapat diketahui bahwa pada ibu hamil yang mengalami kondisi KEK memiliki tingkat kecukupan yang rendah ditandai dengan persentase sebesar $63 \%$ dan $68 \%$ sedangkan kelompok ibu hamil normal juga mengalami kecukupan zat gizi yang kurang ditandai dengan persentase sebesar 62\% dan $63 \%$. Hal ini terjadi diakibatkan karena secara umum kedua kelompok subjek mengonsumsi makanan dalam jumlah kecil atau sedikit dan frekuensi makan yang tidak sering. Berikut adalah sebaran subjek berdasarkan tingkat kecukupan energi dan protein (Tabel 5).

Tabel 5. Sebaran subjek berdasarkan tingkat kecukupan energi dan protein

\begin{tabular}{|c|c|c|c|c|c|c|}
\hline \multirow{2}{*}{$\begin{array}{c}\text { Zat } \\
\text { Gizi }\end{array}$} & \multirow{2}{*}{ Kategori $^{21}$} & \multicolumn{2}{|c|}{ KEK } & \multicolumn{2}{|c|}{ Normal } & \multirow{2}{*}{$\begin{array}{c}p- \\
\text { value }\end{array}$} \\
\hline & & $\mathrm{n}$ & $\%$ & n & $\%$ & \\
\hline \multirow{5}{*}{ Energi } & $\begin{array}{l}\text { Defisiensi } \\
\text { berat } \\
(<70 \% \\
\text { AKEI })\end{array}$ & 22 & 62.9 & 24 & 68.6 & \multirow{5}{*}{$\begin{array}{c}0.759 \\
\mathrm{a}\end{array}$} \\
\hline & $\begin{array}{l}\text { Defisiensi } \\
\text { sedang } \\
(70-79 \% \\
\text { AKEI) }\end{array}$ & 7 & 20 & 2 & 8.6 & \\
\hline & $\begin{array}{l}\text { Defisiensi } \\
\text { ringan (80- } \\
89 \% \\
\text { AKEI) }\end{array}$ & 3 & 8.6 & 6 & 17.1 & \\
\hline & $\begin{array}{l}\text { Cukup (90- } \\
119 \% \\
\text { AKEI) }\end{array}$ & 3 & 8.6 & 2 & 5.7 & \\
\hline & $\begin{array}{l}\text { Lebih } \\
(\geq 120 \% \\
\text { AKEI })\end{array}$ & 0 & 0 & 0 & 0 & \\
\hline \multirow{5}{*}{ Protein } & $\begin{array}{l}\text { Defisiensi } \\
\text { berat } \\
(<70 \%\end{array}$ & 19 & 54.3 & 21 & 60 & \multirow{5}{*}{$\begin{array}{c}0.704 \\
\mathrm{a}\end{array}$} \\
\hline & AKPI) & & & & & \\
\hline & $\begin{array}{l}\text { Defisiensi } \\
\text { sedang } \\
(70-79 \%\end{array}$ & 4 & 11.4 & 5 & 14.3 & \\
\hline & AKPI) & & & & & \\
\hline & $\begin{array}{l}\text { Defisiensi } \\
\text { ringan (80- } \\
89 \% \\
\text { AKPI) } \\
\text { Cukup (90-- }\end{array}$ & 8 & 2.9 & 3 & 8.6 & \\
\hline
\end{tabular}

\begin{tabular}{|c|c|c|c|c|c|c|}
\hline \multirow{5}{*}{$\begin{array}{l}\text { Zat } \\
\text { Gizi }\end{array}$} & \multirow{2}{*}{ Kategori $^{21}$} & \multicolumn{2}{|c|}{ KEK } & \multicolumn{2}{|c|}{ Normal } & \multirow{5}{*}{$\begin{array}{c}p- \\
\text { value }\end{array}$} \\
\hline & & $\mathbf{n}$ & $\%$ & n & $\%$ & \\
\hline & $119 \%$ & & & & & \\
\hline & AKPI) & & & & & \\
\hline & $\begin{array}{l}\text { Lebih } \\
(\geq 120 \% \\
\text { AKPI) }\end{array}$ & 0 & 0 & 0 & 0 & \\
\hline $\begin{array}{l}\text { Uji bed } \\
\mathrm{p}<0.05)\end{array}$ & Mann-W & & $* \mathrm{~B}$ & & sig & kan \\
\hline
\end{tabular}

Keterangan:

AKEI : Angka Kecukupan Energi Individu

AKPI : Angka Kecukupan Protein Individu

Rendahnya tingkat konsumsi pangan dikarenakan ibu hamil sulit makan dalam jumlah yang banyak disebabkan kondisi perut merasa penuh dan tidak nyaman. Frekuensi konsumsi pangan ibu hamil yang mengalami kondisi KEK lebih tinggi dibandingkan ibu hamil normal khususnya pada makanan pokok, bahan pangan sumber protein, dan jajanan. Penelitian ini menunjukkan bahwa konsumsi pangan ibu hamil tergolong rendah ditandai dengan tingkat kecukupan energi dan protein yang termasuk defisiensi tingkat berat pada sebagian besar subjek KEK maupun normal. Selain itu, faktor ketidaksiapan ibu untuk mengimplementasikan makan makanan yang beragam dalam kehidupan sehari-hari akan turut berpengaruh rendahnya konsumsi pangan yang didukung dengan pengetahuan gizi yang rendah khususnya ibu hamil yang mengalami KEK. Hal ini dikarenakan semakin beragam konsumsi pangan maka pemenuhan zat gizi lainnya dapat diterpenuhi dengan baik. Saat melakukan kunjungan wawancara dan recall ditemukan subjek yang hanya mengonsumsi nasi dan taburan garam setiap hari. Hal ini menggambarkan tingkat keberagaman belum dapat terpenuhi.

Sebagian besar tingkat kecukupan protein pada ibu hamil yang mengalami KEK dan normal masih berada dalam kategori kurang ditandai dengan persentase sebesar $85.7 \%$. Tingkat kekurangan asupan protein yang tergolong berat $(57.1 \%)$, sedang $(12.9 \%)$, dan ringan $(15.7 \%)$, sedangkan asupan protein yang tergolong cukup sebesar $14.3 \%$. Selain itu proporsi subjek yang tergolong cukup pada kelompok normal (17.1\%) cenderung lebih tinggi bandingkan kelompok KEK (11.4\%). 
Berdasarkan hasil wawancara berdasarkan FFQ didapatkan bahwa frekuensi konsumsi lauk hewani dan nabati masih berada dalam jumlah yang sedikit dalam hal kuantitas sebesar 4-5 kali seminggu seperti ikan asin, telur ayam, daging ayam, tahu, dan tempe sedangkan bahan pangan lainnya $\leq 3$ kali seminggu seperti udang, cumi, kacang tanah, kacang hijau, dan lain-lain. Hasil dari penelitian ini menunjukkan bahwa tidak terdapat perbedaan yang bermakna pada ibu hamil KEK dan normal berdasarkan kategori tingkat kecukupan energi dan protein ( $p>0.05$ ).

Dampak yang diakibatkan ibu hamil apabila konsumsi pangan yang rendah akan menyebabkan penurunan berat badan sehingga tidak mencapai peningkatan berat badan ideal sesuai rekomendasi. Penelitian ini menunjukkan bahwa sebagian besar ibu hamil yang memiliki status gizi normal memiliki IMT pra-hamil yang tergolong normal. Hal ini menandakan bahwa ibu hamil tersebut memiliki cadangan atau ketersediaan zat gizi di dalam tubuh sehingga apabila ibu dalam kondisi hamil memiliki kondisi yang siap untuk tumbuh kembang janin selama masa kehamilan, sedangkan ibu hamil yang mengalami KEK sebagian besar memiliki IMT yang tergolong kurus yang menandakan ketersediaan atau cadangan zat gizi tergolong kurang sehingga untuk memasuki kondisi kehamilan sangat berisiko mengalami KEK apabila tidak diimbangi dengan asupan makanan yang baik. Berdasarkan hasil penelitian yang dilakukan di wilayah kerja Puskesmas Sewon Bantul Yogyakarta bahwa IMT pra-hamil merupakan faktor yang paling berpengaruh terhadap berat badan lahir bayi. ${ }^{22}$

\section{Ketahanan Pangan Rumah Tangga}

Ketahanan pangan merupakan kondisi terpenuhinya pangan bagi negara sampai dengan perseorangan yang tercermin dari tersedianya pangan yang cukup, baik jumlah maupun mutunya, aman, beragam, bergizi,merata, dan terjangkau serta tidak bertentangandengan agama,keyakinan,dan budaya masyarakat, untuk dapat hidup sehat, aktif, dan produktif secara berkelanjutan. Penelitian ini menggunakan indikator klasifikasi silang berdasarkan tingkat kecukupan energi dan proporsi pengeluaran pangan. ${ }^{23,24}$ Berikut sebaran subjek penelitian berdasarkan ketahanan pangan rumah tangga (Tabel 6).

Tabel 6. Sebaran subjek ketahanan pangan rumah tangga berdasarkan status gizi ibu hamil

\begin{tabular}{|c|c|c|c|c|c|c|c|}
\hline \multirow{2}{*}{$\begin{array}{l}\text { Kate- } \\
\text { gori }^{19}\end{array}$} & \multicolumn{2}{|c|}{ KEK } & \multicolumn{2}{|c|}{ Normal } & \multicolumn{2}{|c|}{ Total } & \multirow[b]{2}{*}{$p$} \\
\hline & $\mathrm{n}$ & $\%$ & $\mathrm{n}$ & $\%$ & $\mathrm{n}$ & $\%$ & \\
\hline $\begin{array}{l}\text { Tahan } \\
\text { pangan }\end{array}$ & 0 & 0 & 2 & 6 & 2 & 6 & \\
\hline $\begin{array}{l}\text { Rentan } \\
\text { pangan }\end{array}$ & 6 & 17 & 22 & 63 & 28 & 63 & 0.000 \\
\hline $\begin{array}{l}\text { Kurang } \\
\text { pangan }\end{array}$ & 5 & 14 & 1 & 3 & 6 & 3 & $\mathrm{a} *$ \\
\hline $\begin{array}{l}\text { Rawan } \\
\text { pangan }\end{array}$ & 24 & 69 & 10 & 29 & 34 & 29 & \\
\hline
\end{tabular}

Sebagian besar ibu hamil KEK berada dalam kondisi rawan pangan sebesar 69\% sedangkan rumah tangga subjek yang mengalami status gizi normal berada dalam kondisi rentan pangan sebesar $63 \%$. Pemenuhan kecukupan konsumsi pangan berdasarkan kecukupan energi merupakan ketahanan pangan dari aspek gizi sedangkan proposi pengeluaran pangan dapat mengukur ketahanan pangan dari aspek ekonomi. Penelitian ini menunjukkan bahwa pada ibu hamil yang mengalami KEK berada dalam situasi rawan pangan ditandai dengan proporsi pengeluaran pangan tergolong tinggi. Kondisi pada rumah tangga tersebut faktor untuk mencapai ketahanan pangan adalah pendapatan dan pengetahuan gizi. Tingkat pendapatan rumah tangga yang baik disertai dengan landasan pengetahuan gizi yang baik diharapkan dapat memperbaiki tingkat konsumsi pangan sehingga dapat mencapai ketahanan pangan. Ibu hamil yang memiliki status gizi normal menunjukkan sebagian besar berada pada situasi rentan pangan ditandai dengan proporsi pengeluaran pangan tergolong tinggi. Kondisi tersebut mengindikasikan bahwa rumah tangga dengan pendapatan yang tergolong rendah akan memprioritaskan untuk membeli bahan pangan dalam memenuhi kecukupan energi. Kondisi rentan pangan erat kaitannya dengan faktor pendapatan, sehingga peningkatan pendapatan dapat mencapai ketahanan pangan. ${ }^{25}$ Hasil dari penelitian ini menunjukkan bahwa 
terdapat perbedaan yang bermakna pada ibu hamil KEK dan normal berdasarkan kategori ketahanan pangan rumah tangga $(\mathrm{p}<0.05)$.

Indikator terbentuknya ketahanan pangan pada tingkat wilayah atau regional adalah ketahanan pangan rumah tangga yang tercermin pada pengeluaran pangan dan non pangan. Semakin besarnya pengeluaran pangan di tingkat rumah tangga maka semakin rendah ketahanan pangan. Zat gizi yang yang menjadi indikator utama dalam ketahanan pangan adalah energi dan protein. ${ }^{24}$

Pendapatan rumah tangga yang tinggi dapat mempengaruhi proporsi pengeluaran pangan. Hal ini menyebabkan pengeluaran pangan tergolong rendah. Pengeluaran pangan dengan bahan pangan yang tersedia sudah tercukupi, sehingga pengeluaran non pangan dapat dilakukan oleh rumah tangga. Selain itu dengan pendapatan yang tinggi dapat mendukung untuk meningkatnya konsumsi energi dan protein sehingga dengan pangsa pengeluaran pangan yang rendah dan konsumsi tercukupi akan mendukung dan menjadikan rumah tangga tergolong tahan pangan. Kondisi rentan pangan erat kaitannya dengan faktor pendapatan, sehingga dengan peningkatan pendapatan rumah tangga dapat mencapai ketahanan pangan. ${ }^{26}$

Penentuan status gizi pada ibu hamil dapat dilakukan dengan menggunakan indikator LILA untuk mengetahui risiko kurang energi kronis yang dapat terjadi dipengaruhi oleh beberapa faktor-faktor penyebab terdiri dari konsumsi pangan yang tercermin dalam tingkat kecukupan energi dan protein, pengetahuan, gizi, dan ketahanan pangan rumah tangga. Berikut adalah hubungan konsumsi pangan, pengetahuan gizi, dan ketahanan pangan rumah tangga (Tabel 7).

Tabel 7. Hubungan Konsumsi Pangan, Pengetahuan Gizi dan Kesehatan, dan ketahanan pangan rumah tangga dengan KEK pada Ibu Hamil

\begin{tabular}{lcccc}
\hline \multirow{2}{*}{ Variabel } & \multirow{2}{*}{$\begin{array}{c}\text { v- } \\
\text { value }\end{array}$} & OR & \multicolumn{2}{c}{$95 \%$ CI for OR } \\
\cline { 4 - 5 } $\begin{array}{l}\text { Konsumsi } \\
\text { Pangan }\end{array}$ & 0.699 & 1.556 & 0.165 & 14.654 \\
\hline
\end{tabular}

\begin{tabular}{lllll}
\hline $\begin{array}{l}\text { Tingkat } \\
\text { kecukupan } \\
\text { energi }\end{array}$ & & & & \\
$\begin{array}{l}\text { Konsumsi } \\
\text { Pangan }\end{array}$ & & & & \\
$\begin{array}{l}\text { Tingkat } \\
\text { kecukupan } \\
\text { protein }\end{array}$ & 0.671 & 1.357 & 0.332 & 5.554 \\
$\begin{array}{l}\text { Pengetahuan } \\
\text { gizi dan } \\
\text { kesehatan }\end{array}$ & 0.044 & 4.500 & 1.044 & 19.394 \\
$\begin{array}{l}\text { Ketahanan } \\
\text { pangan }\end{array}$ & & & & \\
rumah & 0.000 & 0.114 & 0.035 & 0.365 \\
tangga & & & & \\
*Uji regresi logistik & & & \\
\hline
\end{tabular}

Hubungan konsumsi pangan (tingkat kecukupan energi) dengan KEK pada ibu hamil yang menunjukkan bahwa tidak terdapat hubungan yang signifikan ditandai dengan $p$ value $=0.699$. Selain itu, konsumsi pangan (tingkat kecukupan protein) menunjukkan bahwa tidak terdapat hubungan yang signifikan $p$-value $=0.671$. Hasil penelitian ini sejalan dengan penelitian sebelumnya yang dilakukan di Kabupaten Kediri menyatakan bahwa tidak terdapat hubungan antara tingkat kecukupan energi dan protein pada ibu hamil dengan KEK pada ibu hamil. Tingkat kecukupan energi dan protein menunjukkan hubungan yang tidak signifikan dikarenakan konsumsi pangan pada penelitian ini dalam jangka waktu yang singkat sedangkan kejadian KEK berlangsung dalam jangka waktu lama. Kejadian kurang energi kronis tidak hanya dipengaruhi oleh asupan energi dan protein yang diperoleh dari makanan, tetapi semua zat gizi dapat memberi kontribusi pengaruh terhadap kejadian kurang energi kronis. Besarnya pengaruh kejadian kurang energi kronis dapat dilihat dari asupan energi dan protein sebagai prediktor. ${ }^{27,28}$

Hasil analisis variabel selanjutnya adalah hubungan pengetahuan gizi dan kesehatan dengan KEK pada ibu hamil yang menunjukkan bahwa terdapat hubungan yang signifikan ditandai dengan nilai $p$-value $=0.044$ dengan nilai $\mathrm{OR}=4.500$ yang berarti peluang ibu hamil dengan pengetahuan gizi dan kesehatan yang kurang 4.5 kali lebih tinggi untuk mengalami KEK dibandingkan ibu hamil yang 
memiliki pengetahuan gizi dan kesehatan yang baik. Hal ini berarti bahwa semakin baik pengetahuan gizi seseorang maka risiko terkena KEK pada ibu hamil semakin rendah. Penelitian ini sejalan dengan penelitian sebelumnya di Kota Bogor, Depok, dan Pekanbaru menyatakan bahwa terdapat hubungan yang signifikan antara pengetahuan gizi ibu hamil dengan kejadian KEK. Pengetahuan merupakan faktor penting dalam membentuk suatu perilaku individu termasuk perilaku kesehatan individu. Perilaku yang berlandaskan pengetahuan yang baik akan bertahan lama jika dibandingkan perilaku yang tidak berlandaskan pengetahuan. Pengetahuan terkait gizi dan kesehatan akan mempengaruhi konsumsi pangan, hal ini dikarenakan semakin baik pengetahuan gizi ibu maka dalam mengonsumsi makanan beragam sehingga dapat memenuhi kebutuhan zat gizi sehingga pertumbuhan dan perkembangan janin serta kesehatan ibu dapat terjaga dengan baik. ${ }^{29,30,31}$

Hubungan antara ketahanan pangan rumah tangga dengan KEK pada ibu hamil menunjukkan bahwa terdapat hubungan yang signifikan dengan nilai $p$-value $=0.044$ dengan nilai $\mathrm{OR}=0.114$ yang bermakna bahwa peluang ibu hamil dengan ketahanan pangan rumah tangga tergolong rentan pangan sebesar 0.114 kali lebih tinggi untuk berisiko mengalami KEK dibandingkan ibu hamil dengan ketahanan pangan rumah tangga yang tergolong rawan pangan. Semakin baik kondisi ketahanan pangan rumah tangga maka risiko untuk terkena KEK pada ibu hamil semakin rendah. Penelitian ini sejalan dengan penelitian sebelumnya di pedesaan Bangladesh bahwa wanita rumah tangga yang tergolong rawan pangan akan cenderung memiliki lingkar lengan atas dan indeks massa tubuh yang lebih rendah. Hal ini dikarenakan semakin rendah golongan ketahanan pangan rumah tangga berarti semakin rendah asupan energi dan pengeluaran pangan yang tinggi. Ketahanan pangan rumah tangga dapat dijadikan sebagai faktor penentu yang dapat mempengaruhi status gizi ibu. Hal ini didukung dari hasil penelitian bahwa ibu hamil yang memiliki status gizi kurang lebih banyak ditemukan pada rumah tangga yang tergolong tidak tahan pangan. Pengetahuan ibu rumah tangga termasuk salah satu faktor yang menjadi penentu ketahanan pangan rumah tangga. $32,33,34,35$

Variabel yang berpengaruh dengan KEK pada ibu hamil menggunakan analisis regresi logistik berganda dengan menggunakan beberapa variabel yang terdiri dari pekerjaan subjek, pekerjaan suami, usia subjek, usia suami, pendapatan keluarga, besar keluarga, jarak kehamilan, paritas, tingkat kecukupan protein, ketahanan pangan, dan pengetahuan gizi dan kesehatan, sedangkan tingkat pendidikan subjek dan suami, serta tingkat kecukupan energi dikeluarkan. Hal ini dikarenakan variabel tersebut terjadi multikolinearitas antar variabel bebas sehingga sulit untuk melihat pengaruh terhadap KEK pada ibu hamil. Berdasarkan hasil uji regresi logistik berganda menunjukkan bahwa ketahanan pangan merupakan faktor yang berhubungan dengan KEK pada ibu hamil.

Hasil uji regresi logistik berganda didapatkan bahwa peluang seorang ibu hamil yang memiliki ketahanan pangan rumah tangga yang tergolong kurang pangan lebih tinggi untuk berisiko KEK sebesar 2.083 kali dibandingkan ibu hamil yang ketahanan pangan rumah tangga yang tergolong rawan pangan dan variabel lainnya dianggap konstan sedangkan peluang seorang ibu hamil dengan ketahanan pangan rumah tangga yang tergolong rentan pangan lebih tinggi untuk berisiko KEK sebesar 0.114 kali dibandingkan subjek dengan ketahanan pangan tergolong rawan dan variabel lainnya dianggap konstan. Hasil penelitian sebelumnya di kota Binjai bahwa terdapat hubungan yang signifikan antara ketahanan pangan dengan KEK pada ibu hamil. Tingkat ketersediaan pangan masyarakat tidak menjamin terpenuhinya ketersediaan pangan pada tingkat rumah tangga. Hal ini dipengaruhi harga bahan pangan, pendapatan keluarga, dan pengeluaran. Tingkat pengetahuan gizi, kesadaran, dan sosial budaya turut mempengaruhi kondisi ketahanan pangan rumah tangga dikarenakan dengan ketidaktahuan terkait gizi dan kesehatan memiliki risiko mengalami kondisi rawan pangan. Selain itu, ketahanan pangan di tingkat rumah tangga menunjukkan kemampuan rumah tangga untuk 
memenuhi kecukupan pangan dan kemampuan untuk membeli bahan pangan. ${ }^{36,37}$

Tabel 8. Faktor yang paling berpengaruh terhadap kejadian KEK pada Ibu Hamil di Puskesmas Cikembar

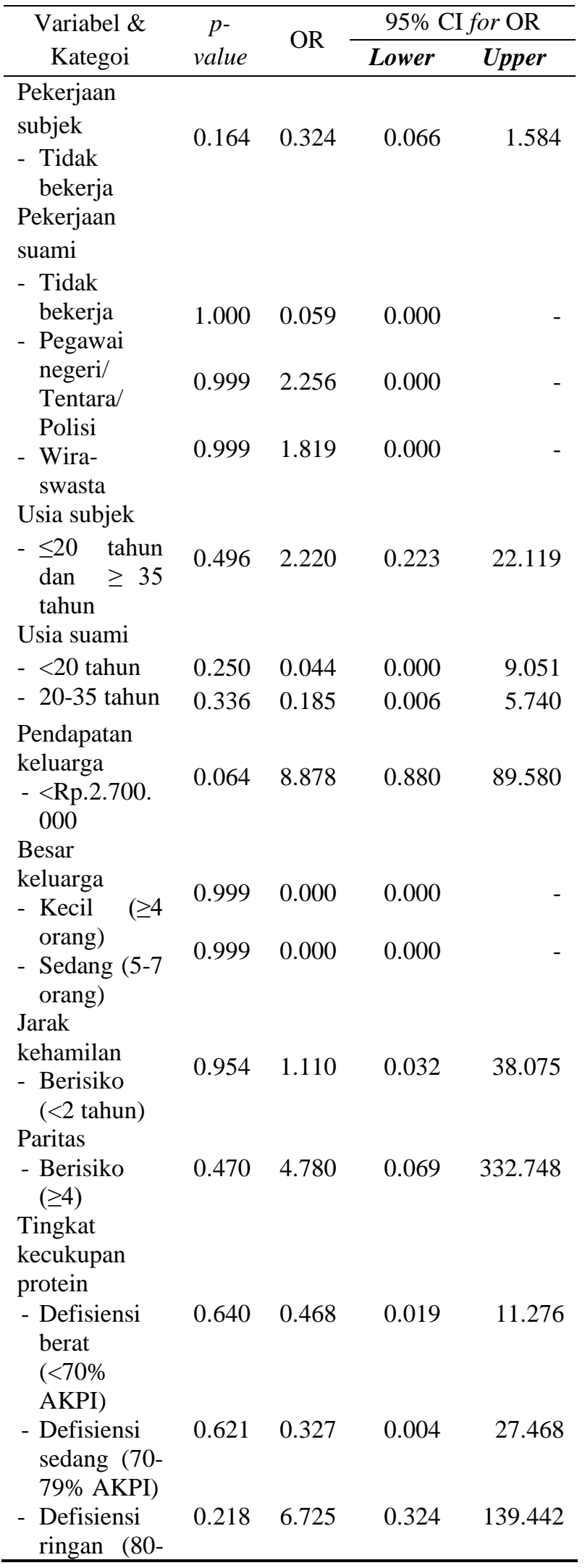

\begin{tabular}{|c|c|c|c|c|}
\hline \multirow{2}{*}{$\begin{array}{c}\text { Variabel \& } \\
\text { Kategoi }\end{array}$} & \multirow{2}{*}{$\begin{array}{c}p- \\
\text { value }\end{array}$} & \multirow{2}{*}{ OR } & \multicolumn{2}{|c|}{ 95\% CI for OR } \\
\hline & & & Lower & Upper \\
\hline $89 \%$ AKPI) & & & & \\
\hline $\begin{array}{l}\text { Ketahanan } \\
\text { pangan rumah } \\
\text { tangga }\end{array}$ & 0.003 & - & - & - \\
\hline $\begin{array}{l}\text { - Tahan } \\
\text { pangan } \\
(>80 \% \\
\text { kecukupan } \\
\text { energi, } \\
<60 \% \\
\text { pengeluaran } \\
\text { pangan) }\end{array}$ & 0.999 & 0.000 & 0.000 & - \\
\hline $\begin{array}{l}\text { - Rentan } \\
\text { pangan } \\
(>80 \% \\
\text { kecukupan } \\
\text { energi, } \\
\geq 60 \% \\
\text { pengeluaran } \\
\text { pangan). }\end{array}$ & 0.000 & 0.117 & 0.036 & 0.384 \\
\hline $\begin{array}{l}\text { - Kurang } \\
\text { pangan } \\
\text { ( } \leq 80 \% \\
\text { kecukupan } \\
\text { energi, } \\
<60 \% \\
\text { pengeluaran } \\
\text { pangan). }\end{array}$ & 0.699 & 1.586 & 0.154 & 16.381 \\
\hline $\begin{array}{l}\text { Pengetahuan } \\
\text { gizi, } \\
\text { kesehatan, } \\
\text { dan } \\
\text { kehamilan }\end{array}$ & & & & \\
\hline - Kurang & 0.107 & $\begin{array}{r}10.84 \\
5\end{array}$ & 0.600 & 196.022 \\
\hline $\begin{array}{l}\text { - Cukup (60- } \\
79 \%)\end{array}$ & 0.263 & 4.948 & 0.301 & 81.290 \\
\hline
\end{tabular}

\section{SIMPULAN DAN SARAN}

Jarak kehamilan dan paritas pada ibu hamil KEK dan normal, sebagian besar masih tergolong tidak berisiko. Selain itu, jarak kehamilan dan paritas kedua kelompok tidak terdapat perbedaan yang bermakna berdasarkan kategori jarak kehamilan dan paritas ( $p>0.05)$. IMT pra-hamil pada ibu hamil KEK sebagian besar berada dalam kategori kurus, sedangkan ibu hamil normal berada dalam kategori normal. Penelitian menunjukkan bahwa terdapat hubungan yang signifikan antara IMT pra-hamil dengan kejadian KEK $(\mathrm{p}<0.05)$ dan terdapat perbedaan yang bermakna berdasarkan IMT prahamil pada kedua kelompok subjek $(\mathrm{p}<0.05)$. 
Pengetahuan ibu tentang gizi, kesehatan, dan kehamilan pada ibu hamil KEK menunjukkan sebagian besar berada pada kategori kurang, sedangkan ibu hamil normal sebagian besar berada pada kategori cukup maupun baik. Penelitian ini menunjukkan bahwa terdapat perbedaan yang bermakna pada kedua kelompok ibu hamil berdasarkan kategori tingkat pengetahuan gizi $(\mathrm{p}<0.05)$. Selain itu, terdapat hubungan yang signifikan antara pengetahuan ibu dan ketahanan pangan rumah tangga dengan KEK pada ibu hamil.

Konsumsi pangan pada subjek kelompok KEK dan normal memiliki jenis dan frekuensi yang cenderung sama. Hasil recall $2 \times 24$ jam, tingkat kecukupan energi dan protein subjek kedua kelompok ibu hamil tergolong kurang. Hasil penelitian ini menunjukkan bahwa tidak terdapat perbedaan yang bermakna kedua kelompok ibu hamil berdasarkan kategori tingkat kecukupan energi dan protein. Selain itu, tingkat kecukupan energi dan protein tidak menunjukkan adanya hubungan yang signifikan terhadap KEK pada ibu hamil ( $\mathrm{p}<0.05)$.

Ketahanan pangan rumah tangga pada ibu hamil KEK sebagian besar berada pada kategori rawan pangan sedangkan ibu hamil normal sebagian besar berada pada kategori rentan pangan. Penelitian ini menunjukkan bahwa terdapat perbedaan yang bermakna kedua kelompok ibu hamil berdasarkan kategori ketahanan pangan rumah tangga dan hubungan ketahanan pangan rumah tangga dengan kejadian KEK menunjukkan hubungan yang signifikan $(\mathrm{p}<0.05)$. Hasil analisis regresi logistik berganda menunjukkan bahwa ketahanan pangan rumah tangga merupakan faktor yang mempengaruhi kejadian KEK pada ibu hamil.

Peningkatan pengetahuan terkait gizi dan kesehatan masih perlu dilakukan khususnya ibu hamil yang mengalami KEK dan pasangan pra-nikah melalui penyuluhan kelas ibu hamil atau konseling pra-nikah yang rutin dilaksanakan atau setiap melakukan kegiatan ANC atau ketika ibu berada di posyandu. Selain itu, untuk meningkatkan ketahanan pangan diharapkan terjadinya peningkatan pendapatan rumah tangga dengan cara pemanfaatan pekarangan rumah sehingga menjadi Kawasan Rumah Pangan Lestari (KRPL) agar dapat mencapai kondisi tahan pangan. Pengembangan KRPL mampu untuk mewujudkan kemandirian pangan rumah tangga, diversifikasi pangan dan gizi, serta menjadi sumber tambahan pendapatan bagi rumah tangga.

\section{UCAPAN TERIMA KASIH}

Kami ucapkan terima kasih kepada Kepala Puskesmas Cikembar Kabupaten Sukabumi, Tenaga Pelaksana Gizi, bidan desa, atas dukungan kepada penulis dalam memberikan masukan dalam proses pengambilan data serta dan subjek yang telah bersedia berpartisipasi dalam penelitian ini.

\section{REFERENSI}

1. Kementerian Kesehatan. Rencana strategi Kementerian Kesehatan tahun 2015 - 2019. Rencana Strategis Kementerian Kesehatan Tahun Rencana Strategis Kementerian Kesehatan Tahun. Jakarta: Kementerian Kesehatan; 2015.

2. World Health Organization. Regional Nutrition Strategy: Addressing Malnutrition and Micronutrient Deficiencies (2011-2015). Washington: World Health Organization; 2012.

3. Kementerian Kesehatan RI Badan Penelitian dan Pengembangan. Hasil Utama Riset Kesehatan Dasar. Kementrian Kesehatan Republik Indonesia. 2018;

4. Pastuty R, KM R, Herawati T. Efektifitas Program Pemberian Makanan TambahanPemulihan pada Ibu Hamil Kurang Energi Kronik di Kota Palembang. Jurnal Ilmu Kesehatan Masyarakat. 2018;9(3):179-88.

5. Rahmaniar. Faktor-faktor yang Berhubungan dengan KEK (Tampa Padang, Sulawesi Barat). Media Gizi Masyarakat Indonesia. 2013;2(1):98-103.

6. Prasodjo NW, Fathonah TY. Tingkat ketahanan pangan pada rumah tangga yang dikepalai pria dan rumah tangga yang dikepalai wanita. Sodality: Jurnal Sosiologi Pedesaan. 2011;

7. Istiany A, Rusilanti. Gizi Terapan. Buku Ajar Ilmu Gizi. Bandung; 2014.

8. Kementerian Kesehatan Republik Indonesia. Kesehatan Ibu dan Anak. Jakarta: Program Kesehatan Anak Kementerian Kesehatan Republik Indonesia; 2015.

9. Kurniawan R, Melaniani S. Hubungan Paritas, Penolong Persalinan dan Jarak Kehamilan dengan Angka Kematian Bayi di Jawa Timur. Jurnal Biometrika dan Kependudukan. 2019;7(2):113.

10. Departemen Kesehatan Republik Indonesia. Ibu 
Sehat Bayi Sehat. Jakarta; 2006.

11. Adriani M, Wirjatmadi B. Pengantar Gizi Masyarakat. Jakarta: Kencana; 2012.

12. Marlenywati. Risiko Kurang Energi Kronis (KEK) Pada Ibu Hamil Remaja (Usia 15-19 Tahun) Di Kota Pontianak Tahun 2010 [skripsi]. Depok: Fakultas Kesehatan Masyarakat Universitas Indonesia; 2010.

13. Supariasa IDN, Bakri, Fajar. Penilaian Status Gizi Edisi Revisi. Jakarta: EGC; 2013.

14. Yazdani S, Yosofniyapasha Y, Nasab BH, Mojaveri M, Bouzari Z. Effect of maternal body mass index on pregnancy outcome and newborn weight. BMC Research Notes. 2012;5(34):1-4.

15. Kementerian Kesehatan Republik Indonesia. Tabel Batas Ambang indeks Massa tubuh (IMT) [Internet]. P2PTM Kementerian Kesehatan Republik Indonesia. 2019. Tersedia pada: http://www.p2ptm.kemkes.go.id/infographicp2ptm/obesitas/tabel-batas-ambang-indeksmassa-tubuh-imt

16. Muslimah AR. Lengan Atas pada Ibu Hamil Trimester I di Puskesmas Umbulharjo I Kota Yogyakarta Tahun 2016 [skripsi]. Yogyakarta: Fakultas Ilmu Kesehatan Universitas 'Aisyiyah.; 2017.

17. Ariyani DE, Achadi EL, Irawati A. Validitas Lingkar Lengan Atas Mendeteksi Risiko Kekurangan Energi Kronis pada Wanita Indonesia. Kesmas: National Public Health Journal. 2012;7(2):83-90.

18. Notoatmodjo S. Metodologi Penelitian Kesehatan. Jakarta: Rineka Cipta; 2010.

19. Khomsan A. Teknik Pengukuran Pengetahuan Gizi. Bogor: Jurusan Gizi Masyarakat dan Sumberdaya Keluarga Fakultas Pertanian Institut Pertanian Bogor; 2000.

20. Kristiyanasari W. Gizi Ibu Hamil. Yogyakarta: Nuha Medika; 2010.

21. Hardinsyah, Tambunan. Angka Kecukupan Energi. Protein. Lemak. dan Serat Makanan Widkarya Nasional Pangan dan Gizi. Jakarta: LIPI, Deptan, Bappenas, BPOM, BPS, Menristek, PERGIZI PANGAN, PERSAGI dan PDGMI.; 2004.

22. Nurhayati E. Indeks Massa Tubuh (IMT) Pra Hamil dan Kenaikan Berat Badan Ibu Selama Hamil Berhubungan dengan Berat Badan Bayi Lahir. Jurnal Ners dan Kebidanan Indonesia. 2016;4(1):1-5.

23. Kristanti D, Ningtyias FW, Rohmawati N. Differences of Food Security between Early and Ideal Marriages in Songgon Sub-district Banyuwangi District, East Java Year 2016. Buletin Penelitian Sistem Kesehatan. 2017;20(3):96-104.

24. Johnson U, D Toole. Household food security and nutrition: A Conseptual Analysis. New York: UNICEF; 1991.

25. Saliem HP, Arianingsih E. Perubahan Konsumsi dan Pengeluaran Rumah Tangga di Perdesaan: analisis data SUSENAS 1999-2005. Bogor;
2008.

26. Purwantini. Pendekatan rawan pangan dan gizi: besaran, karakteristik, dan penyebabnya. Pendekatan rawan pangan dan gizi: besaran, karakteristik, dan penyebabnya. Forum Penelitian Agro Ekonomi. 2014;32(1):1-17.

27. Azizah A, Adriani M. Tingkat Kecukupan Energi Protein pada Ibu Hamil Trimester Pertama dan Kejadian Kekurangan Energi Kronis. Media Gizi Indonesia. 2018;12(1):21-6.

28. King, Burges. Nutrition for Developmen Countries. Swiss: WHO Geneva; 1997.

29. Fitrianingtyas I, Pertiwi FD, Rachmania W. Faktor-Faktor yang Berhubungan dengan Kejadian Kurang Energi Kronis (KEK) pada Ibu Hamil di Puskesmas Warung Jambu Kota Bogor. Hearty. 2018;6(2):1-10.

30. Suryaningsih, Trisusilani. Hubungan Tingkat Pengetahuan Ibu Hamil Tentang Kekurangan Energi Kronik (KEK) dengan Ukuran Lingkar Lengan Atas di Puskesmas Depok III Sleman Tahun 2016. Jurnal Permata Indonesia. 2017;8(1):58-66.

31. Wati L, Ernalia Y, Haslinda L. Hubungan Pengetahuan Mengenai Gizi, Pendapatan Keluarga dan Infestasi Soil Transmitted Helminths dengan Kurang Energi Kronik (KEK) pada Ibu Hamil di Daerah Pesisir Sungai Siak Pekanbaru. Jurnal Online Mahasiswa Fakultas Kedokteran Universitas Riau. 2014;1(2):1-10.

32. Na M, Mehra S, Christian P, Ali H, Shaikh S, Shamim AA, et al. Maternal Dietary Diversity Decreases with Household Food Insecurity in Rural Bangladesh: A Longitudinal Analysis. The Journal of Nutrition. 2016;146(10):210916.

33. Young SL, Plenty AHJ, Luwedde FA, Natamba BK, Natureeba P, Achan J, et al. Household food insecurity, maternal nutritional status, and infant feeding practices among HIV-infected Ugandan women receiving combination antiretroviral therapy. Maternal and child health journal. 2014;18(9):2044-53.

34. Saaka M. How is household food insecurity and maternal nutritional status associated in a resource-poor setting in Ghana? Agriculture and Food Security. 2016;5(11):1-8.

35. Yuliana P, Zakaria WA, Adawiyah R. Ketahanan Pangan Rumah Tangga Nelayan di Kecamatan Teluk Betung Selatan Kota Bandar Lampung. Jurnal Ilmu-ilmu Agribisnis. 2013;1(2):181-6.

36. Fuady TRM. Hubungan Ketahanan Pangan Tingkat Keluarga dengan Anemia, KEK, dan Preeklamsia pada Ibu Hamil di Kecamatan Binjai Selatan Tahun 2014 [skripsi]. Medan: Universitas Sumatera Utara; 2014.

37. Suharyanto. JHM, Darwanto. DH, Widodo S. Determinants of Food Security Among Rice Farming Households in the Province of Bali : An Ordered Logistic Model. Journal of 
ARTERI : Jurnal Ilmu Kesehatan

Economics and Sustainable Development.

2014;5(8):35-43. 